\title{
PIOTR LEWIŃSKI
}

ORCID: 0000-0002-3243-217X

Uniwersytet Wrocławski

\section{Co o obrazie świata mówi nam gramatyka?}

W badaniach nad językowym obrazem świata (JOS) najwięcej uwagi poświęca się leksyce i frazeologii, zapominając o tym, że:

Najtwardszą podstawę jego [JOS — przyp. P.L.] rekonstrukcji stanowi gramatyka. Kategorie osoby, liczby, rodzaju, czasu, trybu, przypadka są dającymi się stosunkowo łatwo obserwować i porównywać w skali interkulturowej mechanizmami konceptualizacji rzeczywistości przez mówiących (Bartmiński 2012: 13).

Struktury gramatyczne, które kształtowały się przez stulecia, utrwaliły się w języku. Z synchronicznego punktu widzenia stanowią często dziwaczne i trudne do wyjaśnienia wyjątki (jak np. repartycja końcówki - $u$ w rzeczownikach rodzaju męskiego liczby pojedynczej), są świadectwem określonego przekazu kulturowego i sposobu postrzegania świata przez daną społeczność. Zgodnie z hipotezą Sapira-Whorfa, głoszącą, że język oddziałuje na myślenie, a w konsekwencji na zachowanie ludzi, rodzi się pytanie: czy jednym ze źródeł specyficznego, negatywnego autostereotypu Polaków nie jest język, którym mówimy? Badania pokazują bowiem, że cudzoziemcy postrzegają Polskę i Polaków w dużo korzystniejszym świetle, niż czynimy to sami (Garncarek 1997).

\section{Antropocentryzm}

Jedną z istotnych cech języka polskiego jest antropocentryzm, który uwidacznia się w utrzymywaniu odrębnych leksemów dla ludzi i zwierząt, np. czasowników: człowiek je, umiera, zwierzę żre, zdycha. Ludzka głowa to zwierzęcy łeb, twarz to pysk, morda czy ryj, włosy to kudły. Poza tym zwierzę to nie „ktoś”, tylko „coś”. Tę różnicę podkreślają już autorzy dziewiętnastowiecznych gramatyk, np.: 
Uwagi względem imion ludzkich i zwierzęcych,

1) Między imionami ludzkiemi a zwierzęcemi dwie zachodzą różnice co do rodzaju: 1) że ludzkie, będąc przez zakończenie swoje jednego rodzaju, mogą przez domyślnią stać się innego rodzaju, a zwierzęce nie mogą. 2) Że w liczbie mnogiej imiona ludzkie, rodzaju męskiego, zachowują pospolicie swój rodzaj, np. dzielny żotniérz, dzielni żotniérze; zwierzęce zaś przechodzą pospolicie do rodzaju żeńskiego, np. dzielny koń, dzielne konie. Przejście tych imion z rodzaju do rodzaju jaśnie i niezawodnie pokazuje się przez żeńskie przymiotnika zakończenie dzielni, dzielne: tudzież przez różne zakończenia słowa w czasie przeszłym, np. żolniérze byli, konie byty (Muczkowski 1825: 32).

Wykształcenie się i rozwój kategorii męskoosobowości miały istotny wpływ na cały system gramatyczny i utrwalony w nim JOS. Po pierwsze, zgramatykalizowany został patriarchalny obraz społeczeństwa, co uwidacznia się zarówno w formach fleksyjnych, jak i wykształceniu się wskaźników deiksy społecznej (social deixis) w postaci zaimków honoryfikatywnych, po drugie, konsekwencją eksponowania pierwiastka ludzkiego jest dość skomplikowany system liczebników.

\section{Hierarchiczno-patriarchalny obraz społeczeństwa}

Ta obserwacja — że Polacy dzielą się na elity i lud, a odległość pomiędzy nimi jest taka jak pomiędzy Paryżem a Senegalem — stanowi kluczowy składnik polskiego autostereotypu. Piszą o nim wszyscy od wieku XIX, a do dziś, w III Rzeczypospolitej, wraca w komentarzach po wyborach, zwłaszcza tych, w których wygrywają partie mniej inteligenckie, a bardziej ludowe. Po roku 2015 PiS uczynił z tego stereotypu broń, nieustannie pokazując swoich przeciwników politycznych jako przedstawicieli „oderwanych od koryta” elit wrogich ludowi - a więc w domyśle wrogich prawdziwej Polsce (Leszczyński 2017: 76-77).

Czy zatem polszczyzna faworyzuje elity? Otóż tak, i to bardzo!

\section{Końcówka -owie (por. Lewiński 2006)}

Wprawdzie Mikołaj Rej pisał: „A niechaj to narodowie wżdy postronni znają", lecz od co najmniej 200 lat owie jest końcówką przysługującą wyłącznie ludziom.

Imiona zwierzęce rodzaju męskiego mogą, z zachowaniem rodzaju, kończyć się w tym przypadku nakształt imion ludzkich, na owie, np. ptaszkowie, 
skowronkowie, bocianowie. Wolności tej wtenczas tylko użyć można, gdy w zwierzętach opisuje się przymiot z ludźmi pospolity, jako to cieszenia się, gniewania i t. d. (Muczkowski 1825: 49).

Pospolicie Rzecz: zwiérzęce w liczbie mnogiéy odmiéniaią rodzáy męzki na żeński; są iednak niektóre $\mathrm{w}$ dawnym rodzaiu używane np. psi, wilcy, a u Poetów: ptászkowie, orłowie, łabędziowie (Kopczyński 1817: 58).

Jeśli chodzi o repartycję końcówki owie, obecnie mamy do czynienia z dość jasnym centrum i rozmytymi peryferiami pełnymi nieregularności i niekonsekwencji. Centrum stanowi tradycyjna patriarchalna rodzina — stąd końcówka -owie dla męskich członków rodziny. Brat jest wyjątkiem historycznym ze względu na to, że współcześnie funkcję mianownika 1. mn. pełni dawny rzeczownik zbiorowy *bratbja, siostrzeniec zaś jest wyjątkiem morfologicznym — wszystkie rzeczowniki zakończone na $\sim e c$ mają końcówkę $\sim y$. Podawany w niektórych gramatykach jako wyjątek kuzyn może przybierać zarówno końcówkę $\sim i$ jak i owie:

kuzyn (...) $m I V, D B$. $\sim a$, Ms. nie; $\operatorname{lm} M$. $\sim$ owie a. i, DB. ów (USJP);

kuzyn $m I V, \operatorname{lm} M$. kuzyni, rzad. kuzynowie, (NSPP).

Dalszą konsekwencją faktu, że to mężczyzna ma rodzinę, jest jej głową, jest występowanie końcówki -owie po niebędących przymiotnikami nazwiskach (czasem imionach) par i rodzin. Tutaj można się dopatrywać wyraźnej funkcji dzierżawczej - wprawdzie jawnie dzierżawcze formy typu: pani Nowakowa, pani inżynierowa, pani Józefowa, a także Nowakówna, Deglerówna odchodzą już w zapomnienie, jednak wciąż bezwyjątkowo rodzina Nowaka = Nowakowie, Piotr z żoną (z narzeczoną, dziewczyną) to Piotrowie, a nie Zosiowie czy Matgosiowie.

Oczywiście, poczucie godności należnej danemu stanowisku jest w dużej mierze intuicyjne i tradycyjne. Obok takich form, jak: bogowie, królowie, carowie, bazyleusowie, hrabiowie, panowie itp., mamy cesarzowie równolegle z cesarze. Jak silne jest poczucie honoryfikatywności najwyższych urzędów i stanowisk, świadczą częste błędne użycia końcówki owie tam, gdzie nie przewiduje tego norma:

prezydent (...), Im M. prezydenci (nie: prezydentowie);

premier $m I V, \operatorname{lm} M$. premierzy (nie: premierowie) NSPP.

Tradycyjnie też mamy inżynierowie albo inżynierzy, ale nie *lekarzowie. Co więcej, doktorzy to raczej 'lekarze', a doktorowie 'osoby ze stopniem naukowym' (także honoris causa oraz doktorowie Kościoła); profesorzy 'nauczyciele szkół średnich', profesorowie 'osoby z tytułem naukowym'. Świadectwa podniosłości końcówki dostarczają stare gramatyki:

Uwaga 3. To zakończanie, imion więcéj w dawnéj mowie niż teraz używane, (gdyż starzy mówili Żydowie, Szwedowie, Hollendrowie, narodowie, pastu- 
chowie), prócz wyżéj wyliczonych okoliczności, ma miejsce w uroczystych mowach, gdzie imiona, które w innych zdarzeniach tego zakończenia nie mają, dla lepszego brzmienia one przybierają, na przykład panowie, kupcowie, Anglikowie, i t. d. (Muczkowski 1825: 49).

Jeszcze mniej regularne jest występowanie końcówki owie w nazwach narodowości i członków plemion. Charakterystyczna jest przewaga tej końcówki w nazwach ludów dawnych i starożytnych, tradycyjnie patriarchalnych, np. Sumerowie, Persowie, Wikingowie, Gallowie, Celtowie, Majowie, Aztekowie, Prusowie, Jaćwingowie, Arabowie itp.; w odniesieniu do narodów współczesnych mamy wprawdzie jedynie poprawną formę Belgowie, ale poza tym przeważa końcówka $\sim i / \sim y$ lub dopuszczalne są formy oboczne: Afganowie albo Afgańczycy, Finowie albo Finlandczycy, Norwegowie albo Norwedzy.

Dzisiaj z końcówką owie używają się tylko formy imion osobowych męskich, oznaczających urzędy, godności, pokrewieństwo, oraz nazwiska rodowe i imiona narodów przeważnie starożytnych; np. panowie, bogowie, królowie, wodzowie, posłowie, gienerałowie, senatorowie, aniołowie, członkowie, świadkowie, ziomkowie, ojcowie, mężowie, zięciowie, staruszkowie, Chodkiewiczowie, Mickiewiczowie, Radziwitłowie, Arabowie, Celtowie, Brytowie, Gallowie, Persowie, Medowie, Frankowie, i t. p. (Kryński 1903: 61).

A skoro pod postacią końcówki owie zgramatykalizowana została honoryfikatywność, nic dziwnego, że zgramatykalizowane jest też zjawisko przeciwne deprecjatywność (Bańko 2002: 147-148), czyli kategoria, która świadczy o głębokim poczuciu hierarchii w społeczeństwie.

Deprecjatywność to kategoria fleksyjna o funkcji prymarnie semantyczno-kulturowej. Ujawnia się ona w mianowniku i wołaczu liczby mnogiej rodzaju męskoosobowego. Neutralna forma męskoosobowa łączy się z męskoosobowymi formami czasowników, przymiotników i zaimków przymiotnych, np. ci dobrzy studenci, poczciwi chtopi, obdarci żebracy. Forma deprecjatywna łączy się z formami niemęskoosobowymi: te dobre studenty, poczciwe chłopy, obdarte żebraki. Deprecjatywność polega tutaj na językowym potraktowaniu osób jak przedmiotów, stąd formy deprecjatywne są stylistycznie nacechowane, z reguły ujemnie (lub rubasznie). Niektóre rzeczowniki, zwłaszcza te negatywnie wartościujące, mają tylko formę deprecjatywną: chamy, draby, półgłówki, zbiry, groszoroby, konowaty, ale np. dzielne przedszkolaki, sympatyczne nastolatki to formy neutralne.

W dawnych gramatykach deprecjatywność nie była wprawdzie traktowana jako kategoria fleksyjna, ale nie znaczy to, że nie była dostrzegana:

Imiona ludzkie, iedén maią rodzáy we wszystkich liczbach. Wszakże, gdy czasem myślimy upodlić niecnotliwą osobę ludzką, i do zwierząt przyrów- 
nać, daiemy iéy zakończenie zwierzęce. Co za subtelność ięzyka! (Kopczyński 1817: 61).

Uwaga 1. Imiona żywotne téj formy mają dwojakie zakończenie, t. j. męskie i żeńskie, jak to niżéj zobaczymy. Uważać jednak należy, że imiona osób wtedy tylko kładą się z zakończeniem żeńskiém, kiedy osoby uważają się jako rzeczy, a zatém w znaczeniu poniżającém, litość, pogardę i t. p. wyrażającém, co w ciągu mowy najlepiéj poznać można; gdyż nie zawsze należy uważać zakończenie żeńskie jako cechę poniżenia lub pogardy np. biedni Trojanie, i biedne Trojany i t. p. (Muczkowski 1825: 49).

\section{Deiksa społeczna — honoryfikatywność}

Język polski ma kilka odpowiedników, które wyrażają formę zaimka drugiej osoby ty. Oprócz regularnych form liczby pojedynczej i mnogiej ty i wy istnieją formy oficjalne, zwane honoryfikatywnymi, wymagane przy zwracaniu się do ludzi innych niż dzieci, członków rodziny i bliskich znajomych, np. we współczesnej polszczyźnie pospolity żul to też pan! Formy te, oparte na rdzeniu pan, rozróżniają liczbę i rodzaj. Według Romualda Huszczy „Wbrew polskiej tradycji gramatycznej możemy z całą świadomością wyrazy pan, pani, państwo zaliczyć do zaimków, a nie do rzeczowników" (Huszcza 1980: 179). Gramatykalizacja formy pan/pani w funkcji zaimków jest zjawiskiem stosunkowo nowym, dawniej używane były one wyłącznie w funkcji rzeczowników w odniesieniu do ludzi co najmniej równych mówiącemu:

Ociec nie ma mówić: idźcie tam panie synu, ale po prostu: idź synu; boby dał znać, jakoby sobie równemu rozkazował, nie sobie poddanemu (Linde 1858: 33).

Już wówczas od rzeczowników mających swoje własne znaczenia podstawowe (pan - mężczyzna, władca, arystokrata, chlebodawca; pani - kobieta, władczyni, arystokratka itp.) kształtowało się użycie form honoryfikatywnych, choć oczywiście nikomu by do głowy nie przyszło użyć ich w odniesieniu do osób z pospólstwa:

2. Pan, cum secunda vel tertia persona verbi, summam exprimunt loquentis humilitatem vel lepiditatem. Jeśli pan pozwoli; niech pan będzie łaskaw; jeżeli pan pozwolisz; bądź panie łaskaw (Linde 1858: 33). 
Pół wieku późniejszy Słownik warszawski podaje, że pan to m.in.:

Pan, a, 3 pp. panu a |panowi, panoju|, 7 pp. o panu a. |o panie|, $1 \mathrm{~m}$. owie a. |panoje, pania|(6 pp. ami a [pany, pen, pón|

1. panujący, władca, król, monarcha: [...] 2. Bóg, Wszechmocny, Najwyższy, Stwórca, Stworzyciel i Władca świata: [...] 3. chlebodawca, człowiek, od którego zależą warunki bytu innych, człowiek rozporządzający innemi, głowa, gospodarz (Karłowicz, Kryński, Niedźwiedzki 1908: 30).

Dopiero na siódmej pozycji pojawia się znaczenie 'mężczyzna', ale ze wskazaniem, że odnosi się to wyłącznie do osób o wysokiej pozycji społecznej:

7. mężczyzna z lepszego towarzystwa: Pokój dla panów. W tańcu: Panie przechodzą na drugą stronę, a panowie zostają w miejscu.

8. jako tytuł osoby = a) używany samodzielnie a. przed imieniem lub nazwiskiem osoby, której tykać nie wypada" (Karłowicz, Kryński, Niedźwiedzki 1908: 31).

„Pani” natomiast w rzeczonym słowniku to przede wszystkim:

a) królowa, monarchini, władczyni: [...] b) chlebodawczyni, kobieta, od której zależą warunki bytu innych, rozporządzajca innemi; głowa, gospodyni: [...] c) kobieta niezależna i zadowolona $\mathrm{z}$ tego oraz z powodu swej zamożności, dama, arystokratka, magnatka, potentatka (Karłowicz, Kryński, Niedźwiedzki 1908: 34).

Również w tym przypadku znaczenie 'kobieta' (oczywiście „z towarzystwa”) pojawia się na szóstej pozycji:

f) niewiasta, kobieta z lepszego towarzystwa, dama: Pokój dla pań (= damski). W tańcu: Panie przechodzą na drugą stronę, a panowie zostają w miejscu. Paniom brzemiennym to ziele szkodzi. Syr. Jak się miewają twoje panie? (= żona i córka). Panie jego były natenczas w kościele. Jeż. g) tytuł dawany niewiastom, którym tykać nie wypada (Karłowicz, Kryński Niedźwiedzki 1908: 35).

Kategorię panów definitywnie próbowała zlikwidować propaganda PRL, chociaż jeszcze w SJPD, wydawanym przecież w latach 1958-1967, podkreślana jest pewna elitarność przysługująca panu! Dopiero na drugim miejscu pojawia się funkcja pana jako zaimka honoryfikatywnego:

pan $m I V$, CMs. -u, Im M. -owie 1. «mężczyzna jako należący do tzw. towarzystwa, czyli warstw dawniej uprzywilejowanych»: [...]

2. «forma grzecznościowa używana przy zwracaniu się do mężczyzny, z którym się nie jest w stosunkach zażyłych, poufałych (przy imieniu, nazwisku, 
tytule zawodowym, urzędowym czy naukowym występuje zarówno w zwrotach skierowanych do niego, jak i w wypowiedziach o nim)» SJPD

Natomiast w USJP z 2003 roku pan to już tylko:

1. «mężczyzna»:

Przyszedł jakiś pan.

Panowie ubrani byli w ciemne garnitury.

2. «forma grzecznościowa używana przy zwracaniu się do mężczyzny, z którym się nie jest w stosunkach rodzinnych, zażyłych, poufałych, lub w rozmowie o nim»:

Pan doktor już przyszedł.

Przepraszam pana, która jest godzina? USJP

Również zaimki dzierżawcze mają formy oficjalne. Formy te także oparte są na rdzeniu pan i oprócz r. męskiego 1. poj., który ma wariantywną formę przymiotnikową pański, stanowią zleksykalizowany dopełniacz odnośnych zaimków osobowych. Huszcza pisał:

Poza zaimkami osobowymi kategoria honoryfikatywności pojawia się w polszczyźnie także i w tzw. zaimkach dzierżawczych 2 i 3 os.; wystarczy zestawić takie pary, jak twój:pański (zawsze 2 os.), twój:pana,jego:pana,jej:pani, wasz:państwa, ich:państwa itd. (Huszcza 1980: 183)

Przykłady:

Nieformalne:

Czy to twój samochód?

Gdzie sa wasze walizki?
Formalne:

Czy to pana/ pański samochód?

Gdzie sa państwa walizki?

\section{Liczebniki}

Antropocentryzm spowodował również wyjątkową komplikację systemu liczebnika, ponieważ ta cecha sprawiła, że prymarnie liczymy nie sztuki (elementy zbioru), ale ludzi, a co za tym idzie — odróżniamy płeć. W polszczyźnie zawsze, na mocy gramatyki, znany jest osobowy skład grupy. Mianowicie: dwaj lekarze to mężczyźni, dwie lekarki to kobiety, a dwoje lekarzy to kobieta i mężczyzna. Podobnie: pięciu uczniów, pięć uczennic i pięcioro uczniów. Winę za całe zamieszanie ponoszą oczywiście ,imiona ludzkie rodzaju męzkiego":

Jeżeli mi kto powie: dla czego taka składnia niema miéjsca w innych imionach n. p. żeńskich, źwiérzęcych, i t. p. ?- Dla tego: że u nas wszędzie imiona ludzkie rodzaju męzkiego mają od imion innych barzo różne wzory 
odmian; które wpływają na odmiany innych części mowy z niémi powiązanych (Deszkiewicz 1843: 209).

Stąd osobna forma liczebnika dla mężczyzn, osobna dla kobiet i osobna dla grup mieszanych. Tylko liczebnik 2 zachował odrębną formę rzeczową: $d w a$. Stąd mamy: dwaj mężczyźni, dwie kobiety, dwa domy i dwoje dzieci.

Dway, trzey, i cztérey, są to przymiotniki, ludzkim tylko imionom rodzaiu męzkiego służące. np. dway bracia, trzey xięża, cztérey żołnierze. Dwa, trzy, cztéry, są także przymiotniki, ale służące wszelkim imionom nawet tym, które w liczbie mnogiéy przeszły do rodzaiu żeńskiego, np. dwa konie, kamienie, stowa. W imionach żeńskich, mówi się zawsze dwie, np. dwie niewiasty, dwie kury, dwie izby (Kopczyński 1817: 68-69).

W odniesieniu do nazw rzeczy nie stosuje się formy męskiej (nie ma rzeczy męskoosobowych), natomiast w odniesieniu do nazw zwykłych obiektów (tzn. takich, które mają liczbę pojedynczą) używa się formy żeńskiej, a do obiektów, których nazwy występują jako pluralia tantum, formy zbiorowej. Koncept ten można ująć w formę prostej tabeli:

\begin{tabular}{|l|l|l|l|}
\hline \multicolumn{1}{|c|}{$\begin{array}{c}\text { Funkcja } \\
\text { prymarna }\end{array}$} & \multicolumn{2}{|c|}{ Forma } & \multicolumn{1}{c|}{$\begin{array}{c}\text { Funkcja } \\
\text { sekundarna }\end{array}$} \\
\hline $\begin{array}{l}\text { Prymarnie } \\
\text { liczymy } \\
\text { osoby: }\end{array}$ & liczebników 3,4 & liczebników $\geq 5$ & $\begin{array}{l}\text { Sekundarnie liczymy } \\
\text { rzeczy (sztuki) }\end{array}$ \\
\hline mężczyzn & trzej, czterej & $\sim \mathrm{u}$ & forma słownikowa \\
\hline kobiety & trzy, cztery & zwykłe \\
\hline $\begin{array}{l}\text { grupy } \\
\text { mieszane }\end{array}$ & troje, czworo & $\sim$ oro & pluralia tantum \\
\hline
\end{tabular}

\section{Wsi spokojna, wsi wesoła}

Problem repartycji końcówek w celowniku rodzaju męskiego jest z morfologicznego punktu widzenia nie do wyjaśnienia. Poszczególne gramatyki podają tylko zdawkowe i niejasne eksplikacje typu:

Końcówka u jest charakterystyczna dla rzeczowników rodzaju nijakiego. Końcówkę tę przybiera ponadto kilka rzeczowników żywotnych i osobowych ${ }^{1}$ rodzaju męskiego (z reguły jednosylabowych): psu, kotu, lwu, ostu, Bogu, chłopcu, bratu, katu//katowi, księdzu, ojcu, chłopu, panu (Grzegorczykowa, Laskowski, Wróbel 1999: 325).

\footnotetext{
${ }^{1}$ A co z rzeczownikiem świat?
} 
Nie lepiej było z eksplikacjami w dawnych gramatykach, z tą różnicą, że częściej podkreślano składnię zaimka $k u$, który we współczesnej polszczyźnie praktycznie występuje już tylko w tekstach pisanych i wyrażeniach idiomatycznych, jak np. droga wiodła ku wiosce; stońce chyliło się ku zachodowi; ku pamięci, tak więc nie ma już mowy o takich formach, jak: „także: ku Krakowu, Lwowu, Ojcowu, Piotrkowu, Tomaszowu, Wilanowu, Stanisławowu, i t. p." (Kryński 1903: 57). Uwagi na temat skracania $\sim$ owi na $\sim$ u powtarzają się w wielu gramatykach, np.:

L. p. p. 3. 1) tak żywotnych jako i nieżywotnych imion kończy się pospolicie na $o w i$, odmieniając $\mathrm{z}$ drugiego przypadku ostatnią samogłoskę $a$ lub $u$ na owi, np. człowieka, ogrodu, konia; człowiekowi, ogrodowi, koniowi.

2) Zgłoskę owi nie tylko w poezyi, ale też w wolnej mowie, możemy skracać na $u$, mianowicie z przyimkiem $k u$, np. ku końcu zamiast końcowi, $k u$ Krakowu

3) Przypadek na $u$, tak w niektórych imionach wszedł w zwyczaj, że go już więcej na owi kończyć nie można, jako to: błaznu, Bogu, bratu, chłopu, chłopcu, czartu, diabłu, katu, księdzu, kwiatu i ojcu, panu, światu, kpu, Łbu i wszystkie jednozgłoskowe, które w dawnych księgach kończą się na owi np. lwu, psu, snu i t. d. (Muczkowski 1825: 46)

Może więc jednak rzeczywiście nie ma nic do gruntu błędnego w słynnym cytacie: „Oczko mu się odlepiło, temu misiu”.

Występowanie końcówki $\sim u$ w celowniku liczby pojedynczej rodzaju męskiego daje się wyjaśnić wyłącznie językowo-kulturowym obrazem dawnego świata i wartości w nim obowiązujących.

- Najpierw mamy świat (światu), z podstawową hierarchią duchową, czyli Bogiem i diabłem (Bogu i diablu/czartu).

— Dalej następuje hierarchia społeczna — pan, ksiądz i chłop (panu, księdzul рори і chtopu).

- Potem mamy hierarchię rodzinną: ojcu, bratu i chłopcu (syn dziedziczy dawną końcówkę drugiej deklinacji, a jako wyraz o bardzo wysokiej frekwencji jest mało podatny na zmiany).

- Następnie - podstawowe zwierzęta domowe: kot, pies i osioł (kotu, psu i ostu), a jeszcze do niedawna koztu.

- Ostatnią grupę tworzą dwa zwierzęta od wieków uważane za symbole państwa i władzy, czyli orzeł i lew (orlu i lwu).

I tu uwaga: chodzi wyłącznie o Boga chrześcijańskiego, pisanego zawsze wielką literą. Inni bogowie mają często systemową końcówkę owi, np.:

- Mieszkańcy miasta pamiętali, jak na rozkaz Babilończyka obtlukiwano stare cegty, robiac miejsce nowemu bogowi.

- Ale trzeba przyznać, że potrafit się sprzeciwić bogowi wojny, choć Guderian widział go jako zahipnotyzowanego przez Hitlera. 
- Mitologia przypisuje łabędzie Apollonowi, bogowi muzyki.

- I wybaczyć, że nie patrzyla na mnie jak na niczemu niewinna istote, lecz złożyła mnie w ofierze wymagajacemu, zagniewanemu bogowi jej osobistego świata. Mężowi. (przykłady pochodzą z Narodowego Korpusu Języka Polskiego, http://www.nkjp.uni.lodz.pl)

Jako żywo przychodzą na myśl takie teksty kultury, jak Krótka rozprawa między trzema osobami, Panem, Wójtem, a Plebanem, którzy i swe i innych ludzi przygody wyczytaja, a takież i zbytki i pożytki dzisiejszego świata Mikołaja Reja z Nagłowic (1543) i o prawie 500 lat młodszy serial telewizyjny Ranczo (20062016). Chyba nie na darmo w badaniach dotyczących cech Polaków najwyższe pozycje zajmują takie wartości, jak: religijni, rodzinni, przywiązani do tradycji. Według badań CBOS sprzed siedmiu lat:

Po ponad dwudziestu latach przemian Polacy zdołali — w opinii społecznej

— zachować cechy konstytutywne dla naszej tożsamości narodowej, takie jak: religijność, patriotyzm oraz przywiązanie do rodziny. Zdaniem większości badanych typowy Polak jest osobą religijną, nastawioną patriotycznie, przedkładającą rodzinę nad pracę (CBOS 2011: 3).

Według zaś najnowszych badań:

Opierając się na autodeklaracjach Polaków określających swój stosunek do wiary i praktyk religijnych, można stwierdzić, że powszechnie deklarowana wiara w Boga jest dość trwałą cechą polskiego społeczeństwa (nadal aż 92\% jego członków określa się mianem katolików) (CBOS 2017: 1).

Reasumując, gramatyka utrwaliła hierarchię wartości znaną od wieków. Najpierw Bóg, potem pan i ksiądz, w końcu rodzina. Mamy gramatyczny wyznacznik małej ojczyzny...

\section{Opozycja SWÓJ-OBCY}

To, że nie przepadamy za obcymi, to fakt znany od wieków. Popularne wśród polskiej szlachty przysłowie głosiło: „Póki świat światem, cudzoziemiec nie może być Polakowi bratem". Cytowany już wcześniej Jan Nepomucen Deszkiewicz tak objaśniał w swojej gramatyce niewystępowanie końcówki owie w nazwach niektórych narodów:

Nakoniec niektóre imiona ludzkie dla ogulnéj narodowej nienawiści nieprzybrały właściwych swoich w tych skłońnikach zakończeń np. Francuz, Szwed, Żyd. Ale tę nienawiść w języku nawet okazaną może czas przyszły zarzuci (Deszkiewicz 1846: 44). 
Jan Józef Lipski w samizdacie z 1981 roku pisał:

Ksenofobia i megalomania narodowa wzajemnie się żywią i wspierają. Wiemy, ile wycierpiała Polska od Rosjan i Niemców - co nie usprawiedliwia przekraczania granic głupoty i nienawiści w stosunku do tych narodów; głupotą i nienawiścią człowiek i naród sam sobie szkodzi. Sfaszyzowani Ukraińcy dali się nam we znaki w latach czterdziestych — tu jednak nawet rachunek krzywd i win jest już inny, niż z Niemcami, co nic nie pomaga Ukraińcom w potocznej świadomości, polskiej. Ale czemu tak często Polak pogardza Czechem („Pepiczkiem”)? Tu widać, jak splata się ze sobą ksenofobia ze zidioceniem (Lipski 1981: 9).

Czy rzeczywiście opozycja SWÓJ-OBCY ma również oparcie w gramatyce? Otóż tak, na przykład w gramatyce języka polskiego występuje dość ścisłe rozróżnienie terytoriów, które stanowiły historycznie część Rzeczypospolitej lub były z nią silnie związane kulturowo, jak np. Syberia, dokąd zsyłano polskich powstańców, czy Węgry, przez lata związane unią personalną z Polską (Ludwik Węgierski, Władysław III Warneńczyk). Wszystkie te terytoria, włączywszy polskie prowincje i regiony, z wyjątkiem tych, które w drugim członie mają nazwę naszego kraju (Wielkopolska i Małopolska), łączą się z przyimkiem na: na Śląsk/ na Śląsu, na Ukrainę/na Ukrainie, na Podole/na Podolu, na Litwę/na Litwie. Terytoria obce, zarówno nazwy krajów, jak i prowincji, łączą się z przyimkami do/w: do Niemiec/w Niemczech, do Francji/we Francji, do Lombardii/w Lombardii, do Prowansjil w Prowansji.

Bardzo silna tendencja (choć nie reguła) do podobnego rozróżnienia: naszeobce pojawia się w końcówce dopełniacza nazw miast. Mało skrupulatny Deszkiewicz pisał:

Imiona wszystkie naszych miast mają 4ty skłońnik na $a$ np. Rzeszowa, Łańcuta, Lwowa, i t. p. Oprócz złożonych s wyrazem gród np. Żmigród, Nowogród, i to dla tego ostatniego wyrazu. Obce miast nazwy idą wedle wzoru np. Londynu, Rzymu, Amsterdamu i t. p. (Deszkiewicz 1846: 29)

Dużo precyzyjniejszy był Muczkowski, który użycie końcówek dopełniacza nazw miast wyjaśniał następująco:

A. $u$ mają: $[\ldots]$

a) ze znaczenia i zakończenia:

a) Imiona miast.

a) które z łacińskiego języka pochodzą, np.: Rzym, Londyn i t. p.

$\beta)$ które są wzięte $z$ francuskiego, niemieckiego i innych nie słowiańskich języków, oprócz zakończonych na berg i burg, które mają w drugim przypadku $a$, np. Lyon, Madryt, Stokholm, Stambut, Bender .

$\gamma)$ zakończone na stok, tok, np. Biatystok, Rosztok.

Wyjmują się, zakończone na burg, berg i pol [...] 
B. a mają:

a) Imiona miast,

a) Imiona miast słowiańskich albo po słowiańsku nazwanych także polskie na in lub yn zakończone, lecz obce nazwiska mające, np.: Lublin, Irkuck, Jarosław, Wrocław', Jawor, Izabelin, Olsztyn.

ß) zakończone na spółgłoski tylko polskiemu językowi właściwe, albo które prawdziwie słowiańskiém nazwiskiem oznaczono, np.: Paryż, Wiedeń.

Zakończone na stok i tok [...]

ү) zakończone na gród, gródek, np.:

Nowogród, Dawidogródek

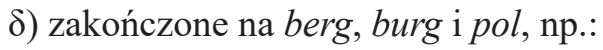

Sztrasburg, Hamburg, Konstantynopol.

— Oprócz Neapol, olu (Muczkowski 1825: 39-41).

Stąd już po końcówkach łatwo rozeznać, co nasze, a co obce. Wprawdzie, podkreślam raz jeszcze, mówimy o tendencjach, a nie ścisłych regułach (bo np. dlaczego jedziemy do Tarnobrzega, ale do Kołobrzegu?), to jednak pokazują one, jak gramatyka kształtuje JOS.

\section{Co złe, to nie my}

W naukach społecznych często przytaczany jest podstawowy błąd atrybucji, zwany błędem aktora-obserwatora. Jest to interpretowanie zjawisk w zależności od tego, czy się w nich uczestniczy, czy się je tylko obserwuje. W skrócie polega to na tym, że gdy jesteśmy podmiotem (aktorami) danego działania, które się nie powiedzie, to zwykle dla zredukowania dysonansu poznawczego thumaczymy swoje zachowanie w kategoriach okoliczności (dokonujemy tak zwanej atrybucji sytuacyjnej), np. pech, stres, fatalne warunki, nadmierne spiętrzenie obowiązków itp. Gdy to samo zachowanie widzimy u innych ludzi (jesteśmy obserwatorami), dokonujemy atrybucji dyspozycyjnej, czyli poszukujemy przyczyn tego działania wewnątrz obserwowanej osoby, np. on/ona jest nieudolny/a, niedouczony/a, brak mu/jej talentu itp. (Zimbardo 1999: 464-465; Aronson, Wilson, Akert 1997: 201 n.). Z tym błędem powiązana jest tendencja samoobronna, czyli dążność do unikania odpowiedzialności poprzez tłumaczenie własnych porażek wpływem środowiska przy ignorowaniu czynników wewnętrznych (charakteru, osobowości). W języku polskim opozycja atrybucja dyspozycyjna — atrybucja sytuacyjna jest w wysokim stopniu zgramatykalizowana - polszczyzna się po prostu kocha w formach zdezagentyzowanych. Dezagentyzacja oznacza, że osoba, o której mowa, nie jest odpowiedzialna za zaistniałą sytuację, będącą całkowicie poza jej kontrolą. Przykłady: 


\section{Agens}

Pomylitem się.

Chce jeść.
Podmiot zdeagentyzowany

Pomylito mi się.

Chce mi sie jeść.

Dezagentyzacja może przybierać różne formy i służą temu określone środki gramatyczne:

1) procesualizacja: transformacja bierna (Awdiejew i Habrajska 2004: 246), np.:

Dziecko jest myte przez matkę (dziecko: pacjens, matka: agens);

2) statyzacja: gerundium (Awdiejew i Habrajska 2004: 246), np.:

Jedzenie mięsa wywołało u Janka podagrę.

(stan: Janek jest chory; deagentyzacja i detemporalizacja: Janek je/jadt mięso);

3) generalizacja polegająca na wyzerowaniu agensa przez wykorzystanie form bezosobowych, $\mathrm{np}$. Znaleziono tajne dokumenty;

4) hipostaza, gdzie funkcję agensa metaforycznie przejmuje onomatoid, np.: ogarną mnie smutek, strach; przyszła mi do głowy pewna myśl, życie ją doświadczyto;

5) użycie podmiotu epistemologicznego w celowniku.

\section{Podmiot epistemologiczny (por. Lewiński 2016).}

Istotą poznania (episteme) i co za tym idzie komunikacji jest przeżywane codziennie przez każdego człowieka doświadczenia ludzkiego poznania, którego rezultat ludzie sobie nawzajem komunikują w języku naturalnym. Ten typ podmiotu odnosi się zatem do osoby, o której jest mowa w zdaniu, bo tylko osoba (tutaj ogólnie rozumiana jako dowolny byt ożywiony) dysponuje zdolnościami poznawczymi. Podmiot epistemologiczny, gdy występuje jako agens, jest tożsamy z podmiotem gramatycznym i wtedy zwykle stoi w mianowniku, natomiast gdy występuje jako podmiot zdezagentyzowany, stoi zazwyczaj w celowniku. Choć składnia tradycyjna dopuszczała podmiot w celowniku: Po co tobie leźć do Soplicowa? (Jodłowski 1976: 68), to jednak w konstrukcjach zdezagentyzowanych traktowany jest on jako dopełnienie dalsze, np.: Nie chciało mi się wstawać. Krótka analiza pokazuje jednak absurdalność takiego (szkolnego) podejścia:

Marza mi się wakacje;

$\begin{array}{lll}\text { Podmiot: } & \text { kto? co? } & \text { wakacje } \\ \text { Orzeczenie: } & \text { Co robiq wakacje? } & \text { marzą się } \\ \text { Dopełnienie: } & \text { Komu się marza? } & \text { mi }\end{array}$

Jest absolutnie oczywiste, że w powyższym przykładzie podmiot występuje w celowniku (bo to wszak ja marzę o wakacjach!), a obiekt (dopełnienie) w mianowniku, wakacje przecież zdolności poznawczo-komunikacyjnych nie mają. 


\section{Czy zatem mi jest podmiotem?}

Pytanie o to, czy ważniejsza jest forma, czy znaczenie, ma już ponadstuletnią tradycję:

Wbrew poglądowi p. Krasnowolskiego, składnia opiera się przeważnie na prawach nie logicznych, ale psychologicznych, a wiadomo, jak prawa w psychologji są jeszcze nieściśle formułowane. Nadto bardzo często mamy w składni do zwalczenia taki szkopuł, jaki przedstawia zmienna odpowiedniość formy i treści. Przy klasyfikacji zdań, lub ich członków, czym mamy się kierować: formą, czy treścią? (Łoś 1908: 322)

Kierujemy się zatem treścią i przyjmujemy, że zarówno w zdaniu Jacek jest smutny, jak i w zdaniu Jackowi jest smutno występuje ten sam podmiot, choć ujęty z innej perspektywy: różny jest jego wpływ na otaczającą rzeczywistość. W zdaniach typu Telewizor mi się zepsut podmiot gramatyczny, systemowo wyrażany mianownikiem, zachowuje się jak quasi-agens; podmiot epistemologiczny, systemowo wyrażany celownikiem, reprezentuje odbiorcę czynności (kogoś niemającego kontroli nad podejmowanymi działaniami, np. marzy mi się, śni mi się, pomyliło mi się). Jeśli zatem w zdaniu występuje obiekt, stoi on w mianowniku, a czasownik wchodzi z nim w związek zgody, czyli reasumując, epistemologiczny podmiot w celowniku jest odbiorcą czynności, której obiektem jest podmiot gramatyczny w mianowniku, np.:

Artykut mi się właśnie drukuje;

Wylała mi się kawa;

Ewie przyśniła się matka.

Co więcej, celownikiem rzadko wyrażany jest beneficjent (jak łaciński dativus commodi) dziejącej się sytuacji, jak np. udało mi się. Najczęściej jest to maleficjent (dativus incommodi), który w ogóle nie ma wpływu na to, co się wokół niego dzieje:

Jestem Polakiem, znającym swój naród i swój kraj. Jedną z chlubniejszych jego cech jest, że różne zniszczenia, straty lub zmarnowania, które w tamtych krajach mają indywidualnych sprawców, u nas nie mają żadnych; [...] Kto od czasów Piasta lub Popiela słyszał, żeby w Polsce ktoś coś stłukł, zniszczył, stracił, strwonił lub sobie przywłaszczył? Były: waza, talerz, lusterko i nie ma ich. Dlaczego? Wiadomo, stłukły się. — Był dobry scyzoryk, a jest połamany: wiadomo: zepsuł się. Gdzie parasol? Zatracił się. Co z pieniędzmi? Rozeszły się. W 1914 roku naród polski posiadał, jak twierdzą ekonomiści, w różnych postaciach dziesięć miljardów franków złotych ruchomego kapitału; teraz go niema. Kto go zniszczył lub skradł? Wiadomo: zmarnował się! (Korwin-Milewski 1930: 204) 
W zdaniach z podmiotem epistemologicznym brak obiektu wyraża stany niezależne od woli, taki podmiot oznacza wówczas odbiorcę stanu emocjonalnego/ fizycznego, nad którym nie ma on kontroli, np.:

Jest mi dobrze/wesoto;

Jackowi jest zimno;

Chce mi się spać.

lub też odbiorcę niekontrolowanych zdarzeń np.:

Umarło jej się na starość i stabe serduszko.

Skoczyto mu ciśnienie.

Zrobiło jej się stabo.

Bardzo pięknym literackim przykładem istotności rozróżnienia podmiotu w mianowniku jako świadomego agensa i podmiotu w celowniku jako nieświadomego pacjensa jest następujący fragment:

Tylko ,gorący Blanchot” naprawdę akceptuje śmierć, tj. czyni ją faktycznie chciana. W wariancie ,zimnym” jednostka, owszem, godzi się na przemijanie, ale godzi się biernie: po prostu daje sobie spokój. To nie jest amor fati, lecz patientia fati: nie umiłowanie losu, tylko jego tolerowanie. Natomiast w „letnim” wariancie w ogóle nie ma mowy o żadnej akceptacji czy chceniu, ponieważ chcieć może tylko jednostka, a w tym wypadku to właśnie ona bezpowrotnie „wytraca się w umieraniu”. Dopiero w wariancie „gorącym" śmierć przestaje być skandalem. I tym razem jednostka odchodzi na zawsze, ale odchodzi pięknie i po swojemu. Umiera tak, jak chce. Na początku człowiek się rodzi; dopiero koniec stanowi pole dla różnicy: „umarł” — lub „umarło mu się" (Stroiński 2007).

\section{Czasowniki nieosobowe}

Z brakiem sprawcy działania związane jest też bogactwo nieosobowych form czasownika. Swego czasu pewien student $\mathrm{z}$ Irlandii zapytał mnie, jaka jest różnica między widziano, widziało się i było widać. Otóż, czasowniki zakończone na no, to odnoszą się tylko do czasu przeszłego. Są to formy ekskluzywne, co oznacza, że mówiący jest wykluczony jako ewentualny agens: zrobił to ktoś, ale nie ja, np. Widziano was razem $w$ restauracji (Ktoś widział, ale nie ja — mnie tam nie było).

Formy nieosobowe z się odnoszą się do wszystkich czasów. Są to formy inkluzywne, co oznacza, że mówiący jest włączony do zbioru potencjalnych agensów, por. np. jedzono - jadto się:

Co jadlo sie w twoim domu rodzinnym?

Co jedzono w Polsce w XVI wieku? 
Czasowniki niefleksyjne: widać, stychać, znać, czuć mają funkcję atrybutywną i odnoszą się wyłącznie do doświadczeń zmysłowych: w danym miejscu jakaś cecha jest poznawalna zmysłowo (znać po niej, że płakała), wzrokiem (z mojego okna widać katedrę), słuchem (przez ścianę było słychać muzykę) lub węchem (czuć tutaj gazem).

Co więcej, w polszczyźnie występuje też spora grupa metapredykatów nieosobowych, takich jak czasowniki niefleksyjne: można, wolno, warto, trzeba, należy, wypada, da się czy też rzeczowniki o funkcji predykatywnej: czas, pora, grzech, nie sposób, strach, szkoda, żal.

\section{Podsumowanie}

Na temat negatywnego autostereotypu Polaków i polskiej kultury narzekania powstało bardzo wiele prac z zakresu nauk społecznych (socjologii, psychologii społecznej itp.). Wynika z nich, że negatywne postrzeganie siebie jako narodu jest ponadklasowe i ponadczasowe:

Polski negatywny autostereotyp okazuje się też wyjątkowo spójny. Niesłychanie różni autorzy — pod względem płci, wykształcenia, poglądów politycznych, zawodu — zarzucają rodakom dokładnie te same negatywne cechy. Podobnie uderzający jest również jego demokratyczny charakter. Publicysta wielkiej gazety ma do zarzucenia rodakom z grubsza to samo co raper z blokowiska. Oczywiście używają różnych słów. Jeden ubiera swoją opinię w socjologiczny kostium, a drugi nie stroni od wulgaryzmów. Sens tego, co mówią o rodakach, jeśli się przyjrzeć, pozostaje jednak zazwyczaj uderzająco zbliżony (Leszczyński 2017: 9).

Lista negatywnych cech przypisywanych Polakom pozostaje jednak niezmienna. Przekracza granice klasy, wykształcenia, majątku i miejsca pobytu. Jest bardzo podobna na forach internetowych i w literaturze pięknej.

Jest to absolutny fenomen (Leszczyński 2017: 9).

Czy może mieć na to wpływ język, którym mówimy? Badania leksyki i frazeologii pokazują, że jakkolwiek autoportret Polski i Polaków nie jest zbyt nowoczesny, ale też nie ma w nim nic złego:

Rekonstrukcja autoportretu Polaka na podstawie danych systemowo-językowych (słownictwa, frazeologizmów, przysłów, utartych kolokacji itp.) daje obraz dość tradycyjny, z dominacją rysów typu rycersko-szlacheckiego, katolika aspirującego do kultury zachodniej i zarazem odstającego od niej swoimi sarmackimi wadami (Bartmiński 2012: 209). 
Co zatem wynika z gramatyki? Przede wszystkim niezwykle silne poczucie hierarchii. Tak jak w języku angielskim łatwo zmienić businessmana na businesswoman albo chairmana na chairwoman, albo jeszcze ogólniej na chairperson, tak po polsku ta sztuczka się nie uda. Zawsze to, co męskie i osobowe, dominuje nad tym, co żeńskie, „źwierzęce” i rzeczowe. Co więcej, osobno liczymy mężczyzn, a osobno całą resztę, czyli kobiety, dzieci, sługi i dobytek domowy.

Honoryfikatywne formy z rdzeniem pan kopią socjalną przepaść, którą Polacy trochę wbrew normie próbują zasypać, łącząc je z czasownikami w 2. osobie: Czy państwo pamiętacie?

Kolejną dość silną dźwignię myślenia stanowi wbudowana w system deprecjatywność. Nawet niekoniecznie potrzeba leksykalnych ,żabojadów” i „,ciapatych", skoro są gramatyczne Francuzy i Hindusy.

Gramatycznie rozróżniamy terytoria oraz miasta swoje i obce, powielając niejako koncepcję ,jedynowłasnego państwa świata”. W tym świecie nie tylko słownictwo i frazeologia dają obraz tradycyjnej polskiej wsi, lecz także taki sam wizerunek można zrekonstruować z końcówek celownika rodzaju męskiego.

I na koniec rzecz najgorsza: język zwalnia nas z odpowiedzialności za to, co czynimy. Nie znam nikogo, kto automatycznie i bez zastanowienia by powiedział: pomyliłem się. Owszem, kiedy trzeba przyznać się do winy i dokonać aktu ekspiacji — tak; ale w codziennych sytuacjach tylko: pomyliło mi się. Wydaje mi się, że sama możliwość bezosobowego mówienia o rzeczach, które trzeba zrobić, albo tych, które się zrobi, jak się będzie chciało, jest w pewien sposób demoralizująca, jak zauważył to w cytowanym wyżej fragmencie stary szlachcic Hipolit Korwin-Milewski.

\section{Bibliografia}

Aronson E., Wilson T.D., Akert R.M. (1997), Psychologia spoteczna: serce i umyst, Poznań. Awdiejew A., Habrajska G. (2004), Wprowadzenie do gramatyki komunikacyjnej, t. 1, Łask. Bańko M. (2002), Wykłady z polskiej fleksji, Warszawa.

Bartmiński J. (2012), Językowe podstawy obrazu świata, Lublin.

CBOS (2011), Stereotyp Polaka i Europejczyka A.D. 2011.

CBOS (2017), Przynależność Polaków do ruchów i wspólnot religijnych.

Deszkiewicz J.N. (1843), Rozprawy o języku polskim i o jego grammatykach, Lwów.

Deszkiewicz J.N. (1846), Grammatyka języka polskiego, Rzeszów.

Garncarek P. (1997), Świat języka polskiego oczami cudzoziemców, Warszawa.

Grzegorczykowa R., Laskowski R., Wróbel H. (red.) (1999), Gramatyka współczesnego języka polskiego. Morfologia, Warszawa.

Huszcza R. (1980), O gramatyce grzeczności, „Pamiętnik Literacki” 71, s. 175-186.

Jodłowski S. (1976), Podstawy polskiej sktadni, Warszawa.

Karłowicz J., Kryński A.A., Niedźwiedzki W. (red.) (1908), Słownik języka polskiego, Warszawa.

Kopczyński O. (1817), Grammatyka języka polskiego przez Onufrego Kopczyńskiego Piiara. Dzieło pozgonne, Warszawa. 
Korwin-Milewski H. (1930), Siedemdziesiąt lat wspomnień, Poznań.

Kryński A.A. (1903), Gramatyka języka polskiego, Warszawa.

Leszczyński A. (2017), No dno po prostu jest Polska. Dlaczego Polacy tak bardzo nie lubia swojego kraju i innych Polaków, Warszawa.

Lewiński P.H. (2006), Czy istnieje fleksja kulturowa?, „Rozprawy Komisji Językowej WTN” 33, s. $139-145$.

Lewiński P.H. (2016), Podmiot i orzeczenie w dydaktyce języka polskiego jako obcego, [w:] O lepsze jutro studiów polonistycznych w świecie: Glottodydaktyka polonistyczna dziś. Monografia zbiorowa, red. P. Gębal, I. Janowska, Kraków, s. 325-340.

Linde S.B. (1858), Słownik języka polskiego przez M. Samuela Bogumiła Linde. Wyd. 2., poprawne i pomnożone, Lwów.

Lipski J.J. (1981), Dwie ojczyzny — dwa patriotyzmy, Warszawa.

Łoś J. (1908), „Antoni Krasnowolski. Systematyczna składnia języka polskiego“ (recenzja), [w:] Prady w nauczaniu języka ojczystego. Praca zbiorowa, red. S. Szober, Warszawa.

Muczkowski J. (1825), Gramatyka języka polskiego, Poznań.

Stroiński M. (2007), Co ty wiesz o umieraniu?, ,artPapier” 22 (94), http://artpapier.com/index.php? page $=$ artykul\&wydanie $=48 \&$ artykul $=1019$.

Zimbardo Ph.G. (1999), Psychologia i życie, Warszawa.

\section{Słowniki}

USJP — Uniwersalny słownik języka polskiego, red. S. Dubisz, t. 1-4, Warszawa 2003.

NSPP — Nowy słownik poprawnej polszczyzny, red. A. Markowski, Warszawa 1999.

SJPD — Stownik języka polskiego, red. W. Doroszewski, wydanie internetowe: http://doroszewski. pwn.pl.

\section{What does grammar tell us about the image of the world?}

\section{Summary}

Grammatical structures, both regular, strongly embedded in the language, and those which are exceptions from a synchronic viewpoint, are not only carriers of certain cultural messages, but also mirrors of the way of perceiving the world.

The lingual representation of the world recorded in the grammar of the Polish language is comprised, among others, of the following features: anthropocentrism, that is observable both in lexis and grammar; a hierarchical-patriarchal structure of society supported by, among other things, the masculine-personal gender and honorific pronouns; xenophobia and national megalomania, and efforts to avoid responsibility. The objective of this paper is to show how language influences the thinking and behaviour of people, and consequently it maintains a specific, negative autostereotype of Poles. The analysed material was excerpted from grammar textbooks originating from the end of the 18th century to the present day.

Keywords: anthropocentrism, autostereotype, grammar, Sapir-Whorf hypothesis, lingual representation of the world 